\title{
Investigation of Catalyst Degradation After Single Cell Life Tests
}

\author{
Tomoyuki Tada, * Nobuhito Toshima, Yumi Yamamoto, \\ and Masahiko INOUE
}

Tanaka Kikinzoku Kogyo K. K. (2-73, Shinmachi, Hiratsuka, Kanagawa 254-0076, Japan)

Received August 8, 2006 ; Accepted October 7, 2006

\begin{abstract}
To investigate the effect of fuel cell operating conditions on catalyst agglomeration of a platinum catalyst, several single cell life tests were carried out under different conditions. It was found that catalyst agglomeration was accelerated by higher temperature operation, while it was not accelerated by higher current density $\left(\sim 1.5 \mathrm{~A} / \mathrm{cm}^{2}\right)$ nor by higher potential $(\sim 0.85 \mathrm{~V})$ when the operating temperature was $100{ }^{\circ} \mathrm{C}$. Catalyst agglomeration was much more severe in the cathode, and the surface area of the platinum catalyst was decreased from $58.9 \mathrm{~m}^{2} / \mathrm{g}$ to $30.6 \mathrm{~m}^{2} / \mathrm{g}$ after a life test for 4000 hours. Because there was no sign of platinum dissolution/precipitation in the ionomer phase and there was a peak tail in the direction of larger particles in the particle distribution after 4000 hours, this catalyst agglomeration may be caused by a crystallite migration mechanism and a coalescence growth mechanism. In addition, to investigate the degradation of the CO-tolerance performance of a platinum-ruthenium catalyst, 5000hour life tests and several life tests for shorter periods were carried out. It was found that the CO-tolerance performance was gradually decreased with time and that one of the reasons for the degradation was considered to be decomposition of the platinum-ruthenium alloy. It was also found that an air-bleeding technique could reduce the loss of cell performance due to the degradation of the CO-tolerance performance but may slightly accelerate the catalyst material degradation.
\end{abstract}

Key Words : Fuel Cell, Platinum Catalyst, Platinum-Ruthenium Catalyst, Degradation

\section{Introduction}

The polymer electrolyte membrane fuel cell has become more and more attractive as the heart of a generator for automotive and household applications, because the performance and durability of the polymer electrolyte membrane fuel cell have been greatly improved as a result of a strong effort in material research and system engineering. Material research could help to understand the degradation mechanism of materials such as the electrocatalyst and membrane.

Reiser et al. ${ }^{1)}$ suggested that the carbon support of the cathode catalyst might be damaged during startup and shutdown because of the reverse current mechanism of protons from the cathode to the anode due to the high interfacial potential differences between the membrane and the cathode during startup and shutdown. Also, many ${ }^{2-5}$ ) reported that the loss of surface area of the electrocatalyst after life tests of the polymer electrolyte membrane fuel cell. Kinoshita et al. ${ }^{6}$ reported that loss of the surface area of platinum could be accelerated by the potential cycling in the liquid electrolyte. Patterson ${ }^{7)}$ investigated the effect of potential cycling on loss of the surface area of platinum in the polymer electrolyte membrane fuel cells and he found a 50\% loss of catalyst surface area after 6500 cycles between 0.87 and $1.2 \mathrm{~V}$. Darling and Mayers ${ }^{8)}$ developed a mathematical model to explain the reason for acceleration of the loss of surface area after potential cycling compared to holding under a steady-state condition. They predicted that the loss of surface area was driven by a potential-dependant dissolution of platinum, chemical dissolution of platinum oxide, and surface tension. Yu et al.9) investigated the effect of potential cycling between $0.87 \mathrm{~V}$ and $1.2 \mathrm{~V}$ on cell performance in the cases of both a platinum catalyst and a platinum-cobalt alloy catalyst. They found platinum band formation in the membrane after potential cycling in the cases of both the platinum and the platinum-cobalt catalyst. They reported that the fuel cell performance of the platinum-cobalt catalyst was stabler after 2400 potential cyclings than that of the platinum catalyst, but formation of the platinum band indicated that future catalyst development would be necessary to improve the stability of platinum.

Taniguchi et al. ${ }^{10)}$ reported that the anode catalyst was severely damaged when fuel starvation occurred, because fuel starvation caused a high anode potential which would lead not only to carbon corrosion but also to ruthenium dissolution. There were several approaches to minimize degradation of the anode catalyst under fuel starvation. ${ }^{11-13)}$ Ye et al. ${ }^{14)}$ reported that the combined technology of using a stabler carbon support and doping with a secondary catalyst for water electrolysis into the anode such as ruthenium oxide, ruthenium-iridium oxide, could minimize degradation of the anode catalyst under fuel starvation.

In addition to the study of catalyst degradation, many ${ }^{15-17)}$ have been investigating the membrane degradation mechanism. Endoh et al. ${ }^{17)}$ reported that fuel cell operation under relatively dry conditions caused the acceleration of membrane degradation. It was also reported that holding the open-circuit potential would accelerate degradation of the membrane. This accelera- 
tion of membrane degradation was considered due to the acceleration of peroxide production under such conditions, some of which would lead to production of hydroxyl radicals which damage the membrane. Also, Ohma et al. ${ }^{18)}$ proposed that platinum band formation in the membrane, which was caused by platinum dissolution in the cathode and platinum reduction in the membrane by hydrogen followed by platinum migration from the cathode to the anode, might accelerate the production of peroxide that would lead to membrane degradation. This implied that stabler electrocatalyst would be necessary not only to minimize degradation of the catalyst itself but also to minimize degradation of the membrane.

These material research studies could help optimize the system design of the fuel cell, and many fuel cell system developers could combine their own knowledge, experience, and their understanding from all kinds of material research to improve durability of their fuel cell systems. We would like to also point out that fuel cell durability has been greatly improved by continuous efforts in optimization of the membrane-electrode assembly, gas diffusion media, and designing of the flow field. These factors could improve the management of water in the fuel cells, which might be one of the most important factors in operation of fuel cell systems.

Concerning catalyst agglomeration of the platinum catalyst, Wilson et $a l_{.}{ }^{3)}$ and Ferreira et $a l^{4}{ }^{4}$ have already published detailed discussions of the mechanism of catalyst agglomeration. Wilson et al. claimed that catalyst agglomeration was caused by a crystallite migration mechanism and a coalescence growth mechanism based on X-ray diffraction analysis, while Ferreira et al. claimed that it was caused by a combination of two mechanisms. One of them is the Ostwald ripening mechanism, which proceeds on a nanometer scale range, and the other is a platinum diffusion/precipitation mechanism, which is caused by the migration of soluble platinum species on a micrometer scale range and chemical precipitation of platinum in the cathode ionomer phase. However, there are still a few studies on catalyst agglomeration after actual fuel cell operation, and also there is almost no fundamental research on the effect of operating conditions on catalyst agglomeration. Therefore, in this study, we investigated the effect of operating conditions on catalyst agglomeration and would like to discuss the mechanism of catalyst agglomeration.

In contrast, for the platinum-ruthenium catalyst, there are only a few studies on the durability of its CO-tolerance performance.5) It is well known that the CO-tolerance performance of platinum-ruthenium catalyst is greatly affected by its characteristics such as alloying conditions, particle size and method of preparing the platinum-ruthenium catalyst. ${ }^{19)}$ Also, the CO-tolerance performance is greatly affected by the system operating conditions and the method of preparing the electrodemembrane assembly, ${ }^{5,20)}$ Moreover, Gottesfeld et al. proposed $^{21)}$ a so-called "air-bleeding technique", which would be able to minimize CO-poisoning by pre-mixing a small amount of air into the fuel. Because there are many parameters to discuss concerning the CO-tolerance performance of a platinum-ruthenium catalyst, it might be relatively difficult to discuss durability of the CO-tolerance performance in a technical report. In this study, we investigated the degradation of the CO-tolerance performance of a platinum-ruthenium catalyst after life tests under constant current operation for several thousand hours with and without air-bleeding.

\section{Experimental}

\section{1 Preparation of catalyst slurry}

TEC10A30S (Tanaka Kikinzoku Kogyo) was used for the investigation of catalyst agglomeration. The platinum loading of this catalyst was $30 \mathrm{wt} \%$, and the platinum particles were supported on high surface area carbon (surface area $=300 \mathrm{~m}^{2} / \mathrm{g}$ ). The particle size of this catalyst by X-ray diffraction analysis was $3.0 \mathrm{~nm}$, and its surface area by CO-chemisorption was $104.2 \mathrm{~m}^{2} / \mathrm{g}$. Nafion ${ }^{\circledR}$ $5 \%$ solution (DuPont) was spray-dried at $120{ }^{\circ} \mathrm{C}$ under nitrogen using spray-dry equipment (GS310, Yamato Kagaku) to obtain Nafion ${ }^{\circledR}$ powder. Then, $1.43 \mathrm{~g}$ of the platinum catalyst, $4 \mathrm{ml}$ of distilled water, and $200 \mathrm{~g}$ of 5 $\mathrm{mm}$ zirconia balls were put in a $250 \mathrm{ml}$ zirconia vessel of a planetary ball mill. After mixing with the planetary ball mill (LP-4, Itoh Seisakusyo) at $200 \mathrm{rpm}$ (rotation:revolution=1:1) for 1 minute, $1 \mathrm{~g}$ of Nafion ${ }^{\circledR}$ powder, $4 \mathrm{ml}$ of 1 propanol, and $4 \mathrm{ml}$ of 2-propanol were added. These materials were mixed again by the planetary ball mill for 50 minutes under the same conditions as above. The catalyst slurry was then separated from the zirconia balls and stored in a refrigerator for 3 days.

TEC61E54 (Tanaka Kikinzoku Kogyo) was used for investigation of the durability of CO-tolerance. The total loading of platinum and ruthenium in this catalyst was $54 \mathrm{wt} \%$, and the catalyst particles were supported on high surface area carbon (surface area $=800 \mathrm{~m}^{2} / \mathrm{g}$ ). The particle size of this catalyst by X-ray diffraction analysis was $3.7 \mathrm{~nm}$. Single peak of the PtRu (220) plane by X-ray diffraction analysis revealed that the platinum and ruthenium in this catalyst were well alloyed. The catalyst slurry was prepared in the same manner as in the case of TEC10A30S. In the case of TEC61E54, the weight of the catalyst and Nafion ${ }^{\circledR}$ powder was changed to $2.17 \mathrm{~g}$ and $1.6 \mathrm{~g}$, respectively. Also, the volumes of distilled water, 1propanol, and 2-propanol for making the catalyst slurry were all changed to $8.5 \mathrm{ml}$.

\section{2 Preparation of gas diffusion layer}

2. 2. 1 Preparation of slurry for Nafion ${ }^{\circledR} /$ carbon layer One gram of carbon (VulcanXC72, Cabot) and $0.8 \mathrm{~g}$ of Nafion ${ }^{\circledR}$ powder were mixed in a planetary ball mill in the same manner as that for the catalyst slurry. The volumes of distilled water, 1-propanol, and 2propanol were all changed to $2.75 \mathrm{ml}$.

2. 2. 2 Hydrophobic treatment on carbon paper Tetrafluoroethylene-hexafluoropropylene copolymer (FEP) solution (FEP-120J, DuPont-Mitsui Fluorochemicals) was diluted with distilled water to 12.4 wt\% FEP content. Carbon paper (TGP-H-120, Toray) was dipped into this solution for 30 minutes and dried at $60{ }^{\circ} \mathrm{C}$ for 30 minutes. After the dipping and drying were repeated 3 
times, the paper was heated at $340{ }^{\circ} \mathrm{C}$ for 15 minutes to remove the surfactant in the solution. The FEP content of the carbon paper was then approximately $30 \mathrm{wt} \%$ and produced a hydrophobic property.


hydrophobic-treated carbon paper The Nafion ${ }^{\circledR} /$ carbon slurry was printed on the hydrophobictreated carbon paper using a bar-coater (K-202, Matsuo Sangyo). A No.9 bar (thickness of the slurry in wet form should be $120 \mu \mathrm{m})$ was used for the coating. After drying at $60{ }^{\circ} \mathrm{C}$ for 5 minutes, the carbon paper was hot-pressed for 1 minute at $130{ }^{\circ} \mathrm{C}$ under a pressure of $20 \mathrm{~kg} / \mathrm{cm}^{2}$.

\section{3 Preparation of electrode}

The catalyst slurry was printed on the prepared gas diffusion layer by a bar-coater. A No.8 bar (thickness of the slurry in wet form should be $100 \mu \mathrm{m}$ ) was used for the first coating. After this coating, the electrode was dried at $60^{\circ} \mathrm{C}$ for 5 minutes and then hot-pressed for 1 minute at $130{ }^{\circ} \mathrm{C}$ under a pressure of $20 \mathrm{~kg} / \mathrm{cm}^{2}$. The catalyst loading on the electrode was controlled at 1 $\mathrm{mg} / \mathrm{cm}^{2}$ of platinum loading in the case of TEC10A30S and $1 \mathrm{mg} / \mathrm{cm}^{2}$ of platinum and ruthenium loading in the case of TEC61E54 by changing the coating times and the bar number. Hot-pressing was done after every coating step.

\section{4 Single cell setup}

Single cells of $25 \mathrm{~cm}^{2}$ area were prepared by sandwiching Nafion ${ }^{\circledR} 112$ (DuPont) with the anode and cathode using carbon plates, each of which had a single serpentine gas flow channel. Compression pressure was controlled by a spring at $25 \mathrm{~kg} / \mathrm{cm}^{2}$ (=(total pressure) / (the exact contact area)). In the case of an investigation of catalyst agglomeration, a TEC10A30S electrode was used for both the anode and cathode. In the case of a study of degradation of the CO-tolerance performance, a TEC61E54 electrode was used for the anode and a TEC10A30S electrode was used for the cathode.

\section{5 Investigation of catalyst agglomeration}

\section{5. 1 Measurement of polarization curve Before} and after the life tests, a polarization curve was measured using our original single cell test station. Cell temperature was controlled at $80^{\circ} \mathrm{C}$, and the flow rate of hydrogen and oxygen were controlled at $1000 \mathrm{ml} / \mathrm{min}$ under atmospheric pressure. A polarization curve was measured from open circuit to the limiting current density in a constant current mode with fully humidified hydrogen and dry oxygen. To evaluate the catalytic activity more precisely, mass activity was calculated by the current density at $0.9 \mathrm{~V}$ from the polarization curve.

\section{5. 2 Life test measurements Life tests were} conducted using our original single cell life test station. For the first experimental, 300-hour life tests were carried out at $60{ }^{\circ} \mathrm{C}, 80^{\circ} \mathrm{C}$, and $100{ }^{\circ} \mathrm{C}$ at a constant current operation of $0.5 \mathrm{~A} / \mathrm{cm}^{2}$ with fully humidified hydrogen (in case of the life test at $100{ }^{\circ} \mathrm{C}$, the bubbler temperature was just controlled at $100{ }^{\circ} \mathrm{C}$ ) and dry oxygen under atmospheric pressure. Stoichiometry of the hydrogen and oxygen was controlled at 1.25 and 2, respectively. The second 300-hour life tests were carried out at $0.004 \mathrm{~A} / \mathrm{cm}^{2}, 0.5 \mathrm{~A} / \mathrm{cm}^{2}$, and $1.5 \mathrm{~A} / \mathrm{cm}^{2}$ at a temperature of $100{ }^{\circ} \mathrm{C}$. Other conditions were the same as in the first life tests. The third life tests were then carried out at $100{ }^{\circ} \mathrm{C}$ under a constant current operation of $1.5 \mathrm{~A} / \mathrm{cm}^{2}$ for 300 hours, 1100 hours and 4000 hours. Other conditions were the same as in the previous life tests.

2. 5. 3 Catalyst analysis before and after life tests Before and after the life tests, the catalyst surface area was evaluated by cyclic voltammetry at $80{ }^{\circ} \mathrm{C}$ just after $\mathrm{I}-\mathrm{V}$ measurement. Fifty $\mathrm{ml} / \mathrm{min}$ of fully humidified hydrogen was supplied to the anode, and $20 \mathrm{ml} / \mathrm{min}$ of dry nitrogen was supplied to the cathode during the cyclic voltammetry measurement. The platinum surface area was calculated from the peak area of atomic hydrogen desorption. For a transmission electron microscope (TEM) observation, the catalysts were carefully scraped from the membrane-electrode assembly with a spatula, and some of them were ultrasonically dispersed into a mixture of water and ethanol, then the dispersed catalysts were scooped out with a copper mesh. After drying them under vacuum, the particle size and particle distribution of the sample were observed by TEM (JEM-2010, JEOL). Also, the scraped catalysts were collected and pressed into a sample holder for X-ray diffraction (XRD) measurement, and the particle size was measured by XRD (JDX-8030, JEOL).

\section{6 Investigation of durability of CO-tolerance}

2. 6. 1 Measurement of CO-tolerance Before and after the life tests, the CO-tolerance performance was evaluated using our original single cell test station. The CO-tolerance performance was measured by evaluation of the voltage drop when the fuel was changed from pure hydrogen to a simulated fuel of $75 \%$ hydrogen, $25 \%$ $\mathrm{CO}_{2}$ and $100 \mathrm{ppm} \mathrm{CO}$ at a constant current of $0.5 \mathrm{~A} / \mathrm{cm}^{2}$. Cell temperature was controlled at $70{ }^{\circ} \mathrm{C}$, and the stoichiometry of hydrogen and air was controlled at 1.25 and 2 , respectively, under atmospheric pressure. The dew point of hydrogen and air was controlled by a bubbler system at $70{ }^{\circ} \mathrm{C}$ and $50{ }^{\circ} \mathrm{C}$, respectively.

2. 6. 2 Life test measurements Four life tests for 5000 hours were carried out using our original single cell life test station. Current density was continuously controlled at $0.5 \mathrm{~A} / \mathrm{cm}^{2}$ at a temperature of $80^{\circ} \mathrm{C}$. Two of the life tests were done without air-bleeding, and a fully humidified mixed fuel of 75\% hydrogen, $25 \% \mathrm{CO}_{2}$ and 100 ppm CO was supplied to the anode. The other two life tests were done with air-bleeding, and a fully humidified mixed fuel of 73.5\% hydrogen, 24.5\% $\mathrm{CO}_{2}, 100$ ppm $\mathrm{CO}$ and $2 \%$ air was supplied to the anode. Dry oxygen was supplied to the cathode, and the stoichiometry of hydrogen and oxygen was controlled at 1.25 and 2 , respectively. Also, several life tests for shorter periods were conducted under the same conditions to collect data for the CO-tolerance durability after 500 hours, 1000 hours, 1500 hours, and 2000 hours.

2. 6. 3 Catalyst analysis before and after life tests In addition to a CO-tolerance performance measurement, a TEM observation was carried out to investigate the particle size and particle distribution in the same 
manner as written in 2.5.3. Also, an XRD analysis was conducted to evaluate the alloying conditions of the platinum-ruthenium catalyst.

\section{Results and Discussion}

\section{1 Investigation of catalyst agglomeration}

Figure 1 shows the variation in cell voltage in the 300hour life tests at $60^{\circ} \mathrm{C}, 80^{\circ} \mathrm{C}$, and $100^{\circ} \mathrm{C}$ at a current density of $0.5 \mathrm{~A} / \mathrm{cm}^{2}$. The average cell voltage during the life tests was $721 \mathrm{mV}$ at $60{ }^{\circ} \mathrm{C}, 720 \mathrm{mV}$ at $80^{\circ} \mathrm{C}$ and 624 $\mathrm{mV}$ at $100^{\circ} \mathrm{C}$, and there was almost no performance loss during this operation in all cases. A lower performance in the case of the life test at $100{ }^{\circ} \mathrm{C}$ was mainly caused by the lack of humidification because of the $100{ }^{\circ} \mathrm{C}$ operation under non-pressurized conditions. Figure 2 shows the catalyst surface area of cathode measured by cyclic voltammetry and the catalyst particle size measured by XRD of both anode and cathode after the life tests. Cyclic voltammetry and XRD analysis on the fresh catalyst revealed that the initial value of the catalyst surface area was $58.9 \mathrm{~m}^{2} / \mathrm{g}$ and the catalyst particle size was 3.0 $\mathrm{nm}$. Under each condition, the catalyst surface area became smaller after the life test. Loss of the catalyst surface area was greatly affected by the operating tem-



Fig 1 Cell voltage as a function of single cell runtime. Cell temperature was controlled at $60^{\circ} \mathrm{C}, 80^{\circ} \mathrm{C}$ and $100^{\circ} \mathrm{C}$.

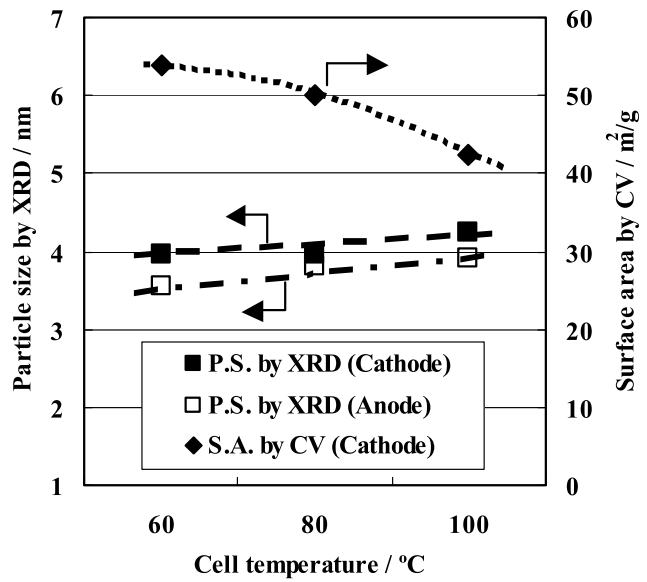

Fig 2 Particle size of platinum in anode and cathode measured by XRD and platinum surface area in cathode measured by $\mathrm{CV}$ after 300 -hour life tests at $60^{\circ} \mathrm{C}, 80^{\circ} \mathrm{C}$ and $100{ }^{\circ} \mathrm{C}$. perature, and the loss became larger with increasing operating temperature. XRD analysis showed that the catalyst particle size was increased after the life tests, and also a small tendency for the catalyst particle size after the life tests to become larger with increasing operating temperature was found in the cases of both anode and cathode. XRD data also suggested that the catalyst particle size of the cathode became larger than that of the anode after the life tests.

Figure 3 shows the variation in cell voltage in the 300hour life tests at $100{ }^{\circ} \mathrm{C}$ at current densities of 0.004 $\mathrm{A} / \mathrm{cm}^{2}, 0.5 \mathrm{~A} / \mathrm{cm}^{2}$, and $1.5 \mathrm{~A} / \mathrm{cm}^{2}$. The average cell voltage during the life tests was $854 \mathrm{mV}$ at $0.004 \mathrm{~A} / \mathrm{cm}^{2}, 624$ $\mathrm{mV}$ at $0.5 \mathrm{~A} / \mathrm{cm}^{2}$ and $398 \mathrm{mV}$ at $1.5 \mathrm{~A} / \mathrm{cm}^{2}$, and there was almost no performance loss during the 300-hour life tests in all cases. Figure 4 shows the evaluation results on catalyst characterization after the life tests at different current densities. Figure 4 shows that the catalyst surface area was decreased from $58.9 \mathrm{~m}^{2} / \mathrm{g}$ to about 42 $\mathrm{m}^{2} / \mathrm{g}$ in all cases, and the catalyst particle size of both anode and cathode was increased from $3.0 \mathrm{~nm}$ to 3.9-4.6 $\mathrm{nm}$ after the life tests. It was found that, under these conditions (current density from $0.004 \mathrm{~A} / \mathrm{cm}^{2}$ to 1.5

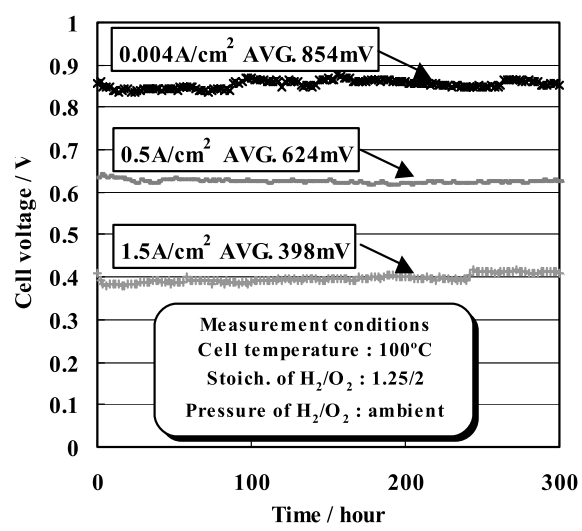

Fig 3 Cell voltage as a function of single cell runtime. Current density was controlled at $0.004 \mathrm{~A} / \mathrm{cm}^{2}, 0.5 \mathrm{~A} / \mathrm{cm}^{2}$, and $1.5 \mathrm{~A} / \mathrm{cm}^{2}$.

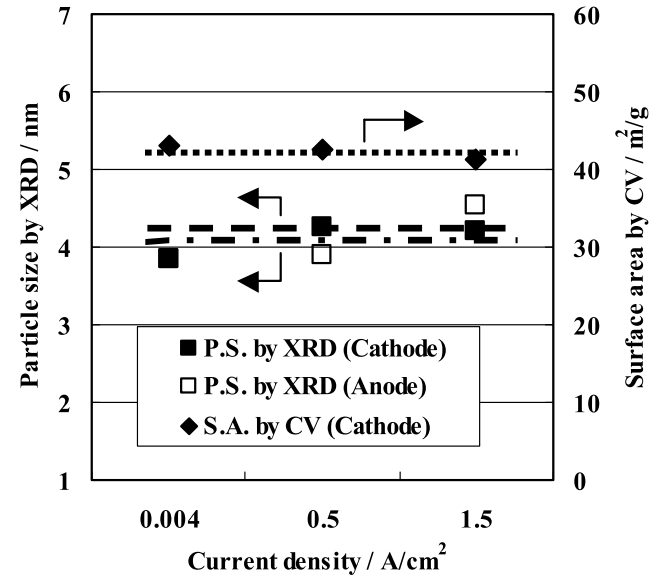

Fig 4 Particle size of platinum in anode and cathode measured by XRD and platinum surface area in cathode measured by $\mathrm{CV}$ after 300 -hour life tests at $0.004 \mathrm{~A} / \mathrm{cm}^{2}$, $0.5 \mathrm{~A} / \mathrm{cm}^{2}$, and $1.5 \mathrm{~A} / \mathrm{cm}^{2}$. 
$\mathrm{A} / \mathrm{cm}^{2}$; in other words, a cathode potential from approximately $398 \mathrm{mV}$ to $854 \mathrm{mV}$ (anode potential during the life tests should be near zero)), the current density did not affect the loss of catalyst surface area and the agglomeration of catalyst particles. We have to point out that there was a possibility that because the life tests were carried out at a relatively high temperature of $100{ }^{\circ} \mathrm{C}$, the temperature effect might be too large to observe the effect of current density on the loss of catalyst surface area and the agglomeration of catalyst particles.

Figure 5 shows the change in catalyst surface area and catalyst particle size after the life tests at $100{ }^{\circ} \mathrm{C}$ at a current density of $1.5 \mathrm{~A} / \mathrm{cm}^{2}$ for up to 4000 hours. The average cell voltage in the 300-hour life test, 1100-hour life test, and 4000-hour life test was $398 \mathrm{mV}, 406 \mathrm{mV}$, and $379 \mathrm{mV}$, respectively. Almost no performance drop was observed during the life tests up to 1100 hours, while there was about a $20 \mathrm{mV}$ performance loss during the

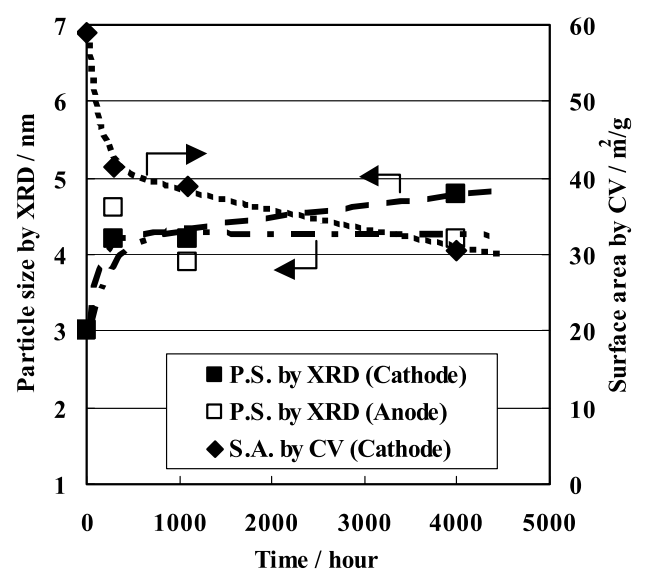

Fig 5 Particle size of platinum in anode and cathode measured by XRD and platinum surface area in cathode measured by $\mathrm{CV}$ as a function of lifetime. Single cells were operated with $\mathrm{H}_{2} / \mathrm{O}_{2}$ (stoichiometry of $1.25 / 2$ ) at $1.5 \mathrm{~A} / \mathrm{cm}^{2}$ under $100{ }^{\circ} \mathrm{C}$. life test for 4000 hours. Figure 5 shows that the catalyst surface area of the cathode was significantly decreased only after the 300-hour life test and kept on decreasing until 4000 hours. After 4000-hour operation, the catalyst surface area decreased to almost half, $30.6 \mathrm{~m}^{2} / \mathrm{g}$, from $58.9 \mathrm{~m}^{2} / \mathrm{g}$. Figure 5 also shows that the catalyst particle size of both cathode and anode was increased significantly during the first 300-hour life test, and the rate of agglomeration slowed in the case of the cathode, while it became negligible in the case of the anode. Figure 6 shows the TEM view of the catalyst particles and dispersion conditions before and after the life tests. These data also show that the catalyst particles became larger only after the 300-hour life test in the cases of both anode and cathode. In the case of the cathode, it seemed that the catalyst particles increased continuously up to 4000 hours, while there was almost no change in particle size after the 300-hour life test in the case of the anode. This difference in the catalyst agglomeration phenomenon between anode and cathode might be caused by the potential difference, local heat generation at the cathode, and a difference in water content.

Ferreira $e t a l^{4)}$ proposed that the loss of catalyst surface area was caused by two mechanisms. One was a nanometer-scale Ostwald ripening mechanism, and the other was a micrometer-scale platinum diffusion/precipitation mechanism based on a detailed observation of TEM analysis by localized sampling in the thickness direction of the catalyst layer. They could observe relatively larger particles which were surrounded by ionomer in the section close to the membrane by TEM observation. Also, the existence of larger particles which were isolated from the electrochemical reaction was supported by the fact that the catalyst particle size measured by XRD was much larger than that obtained by cyclic voltammetry. They also claimed that the contribution to loss of the catalyst surface area from these two mechanisms was almost equal.

In this study, the catalyst surface area of the cathode

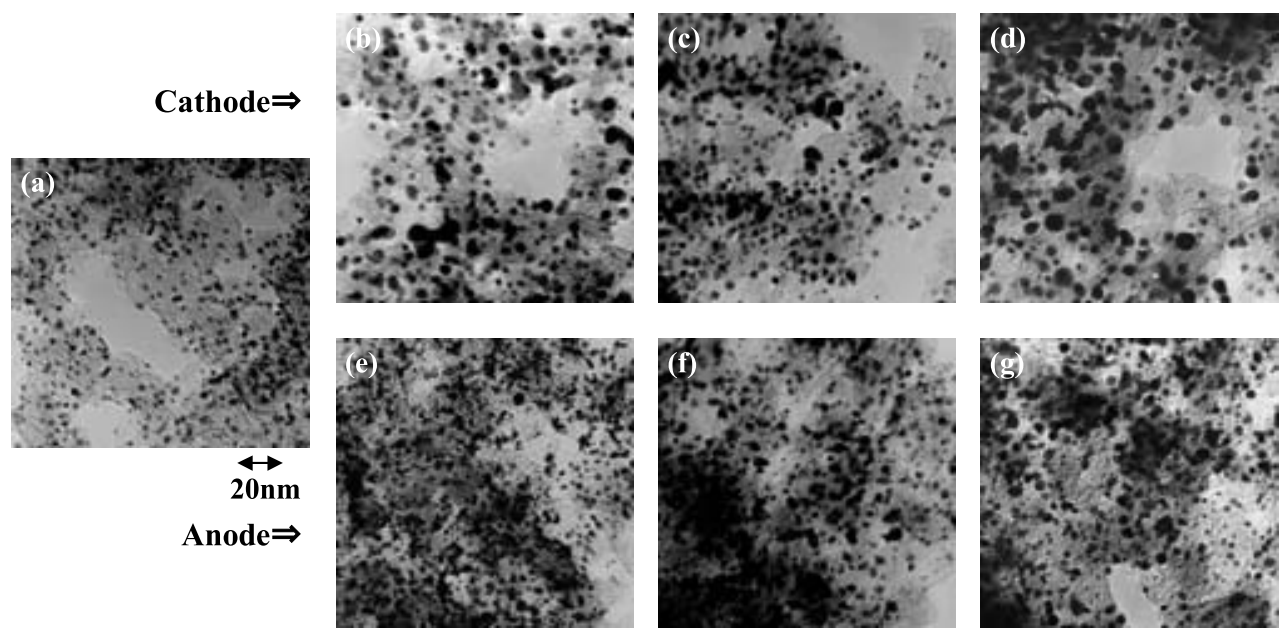

Fig 6 Transmission electron micrographs of platinum catalyst from (a) anode and cathode before life test (b) cathode after 300 hours (c) cathode after 1100 hours (d) cathode after 4000 hours (e) anode after 300 hours (f) anode after 1100 hours and (g) anode after 4000 hours. 
measured by cyclic voltammetry became $51.9 \%$ of the initial value after the 4000-hour life test. TEM observation revealed that the average catalyst particle size of the cathode before and after the life test for 4000 hours was $3.12 \mathrm{~nm}$ and $5.78 \mathrm{~nm}$, respectively. One can roughly calculate the surface area from the particle size on the assumption that the catalyst particles are round and uniform using the following equation,

$$
\mathrm{S}_{\mathrm{Pt}}=6000 /\left(\mathrm{d}_{\mathrm{Pt}} \times \mathrm{D}_{\mathrm{AVERAGE}}\right)
$$

where $\mathrm{S}_{\mathrm{Pt}}$ is the specific surface area of platinum in $\mathrm{m}^{2} / \mathrm{g}$, $\mathrm{d}_{\mathrm{Pt}}$ is the specific density of platinum; $21.45 \mathrm{~g} / \mathrm{cm}^{3}$, and $\mathrm{D}_{\text {AVERAGE }}$ is the average diameter of platinum particles in $\mathrm{nm}$. Calculated catalyst surface area from the particle size based on TEM observation before and after the life test was $89.7 \mathrm{~m}^{2} / \mathrm{g}$ and $48.4 \mathrm{~m}^{2} / \mathrm{g}$, respectively. Therefore, after the life test, the catalyst surface area of the cathode became $53.9 \%$ of the initial value based on the TEM observation. The ratio of the loss of catalyst surface area was well matched between the value by cyclic voltammetry measurement and that based on TEM observation; therefore, the loss of catalyst surface area might be simply explained by the increasing catalyst particle size. Catalyst utilization in the catalyst layer can be defined as;

$$
\mathrm{U}_{\mathrm{Pt}}=\mathrm{S}_{\mathrm{Pt}}{ }^{\mathrm{CV}} / \mathrm{S}_{\mathrm{Pt}}^{\mathrm{TEM}}
$$

where $\mathrm{U}_{\mathrm{Pt}}$ is catalyst utilization in the catalyst layer, $\mathrm{S}_{\mathrm{Pt}}{ }^{\mathrm{CV}}$ is the specific surface area of platinum in $\mathrm{m}^{2} / \mathrm{g}$ measured by cyclic voltammetry, and $\mathrm{S}_{\mathrm{Pt}}{ }^{\mathrm{TEM}}$ is the specific surface area of platinum in $\mathrm{m}^{2} / \mathrm{g}$ based on TEM observation. The catalyst utilization in the cathode catalyst layer before and after the life test was then $65.7 \%$ and $63.2 \%$, respectively. Platinum utilization was almost the same before and after the life test, which indicated no sign of the platinum particles being isolated from the electrochemical reaction.

Using equation 1 , the catalyst particle size of the cathode can also be roughly calculated from the catalyst surface area measured by cyclic voltammetry. The catalyst particle size of the cathode based on cyclic voltammetry before and after the 4000-hour life test was $4.7 \mathrm{~nm}$ and $9.1 \mathrm{~nm}$, respectively. XRD analysis disclosed that the catalyst particle size of the cathode before and after the life test was $3.0 \mathrm{~nm}$ and $4.8 \mathrm{~nm}$, respectively. Thus, the catalyst particle size based on XRD analysis was found to be much smaller than that measured by cyclic voltammetry. This also suggested that there were no larger particles which were isolated from the electrochemical measurement. Therefore, the crystallite migration mechanism and the coalescence growth mechanism, as Wilson et al. proposed $^{3)}$, should be the dominant reactions in catalyst agglomeration in this study. Disagreement with the Ferreira et al. proposal $^{4)}$ might be explained by the difference in operating conditions. In this study, the average cell voltage for the 4000-hour life test was $379 \mathrm{mV}$, and so the cathode potential was approximately $379 \mathrm{mV}$ because the anode potential was almost zero. This poten- tial was too low to accelerate platinum dissolution that would lead to the micrometer-scale platinum diffusion/precipitation mechanism.

Figure 7 shows a comparison of particle distribution before and after the life test for 4000 hours. This clearly shows that the agglomeration of catalyst particles was more dominant in the cathode and that a peak tail was observed in the direction of larger particles in the cases of both anode and cathode. Granqvist and Buhrman's model said ${ }^{22)}$ that a peak tail in the direction of larger particles in a particle distribution analysis could prove that particle agglomeration should be caused by a coalescence growth mechanism, while a peak tail in the direction of smaller particles could prove that particle agglomeration should be caused by the Ostwald ripening mechanism. This model suggested that catalyst agglomeration in the cases of both anode and cathode should be caused by the crystallite migration mechanism and the coalescence growth mechanism. However, especially in the case of the anode, a more detailed discussion like that for the cathode case will be necessary to confirm the mechanism of catalyst agglomeration.

Figure 8 shows a comparison of the polarization curve and the mass activity value before and after the life tests. Figure 8 shows that there was almost no perfor-

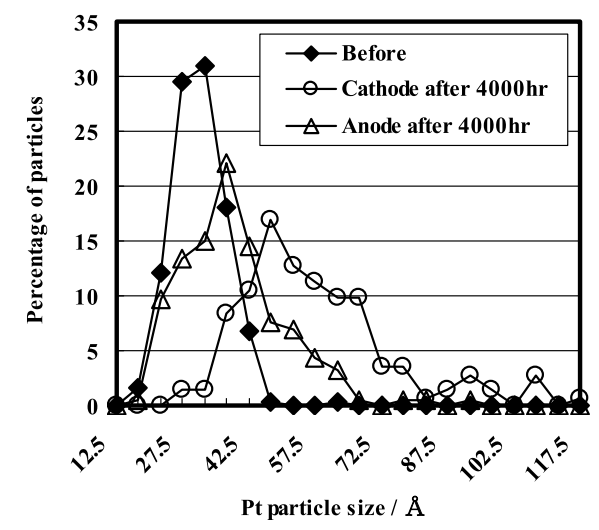

Fig 7 Platinum particle size histograms measured from TEM micrographs in Fig. 6 (a), (d), and (g).

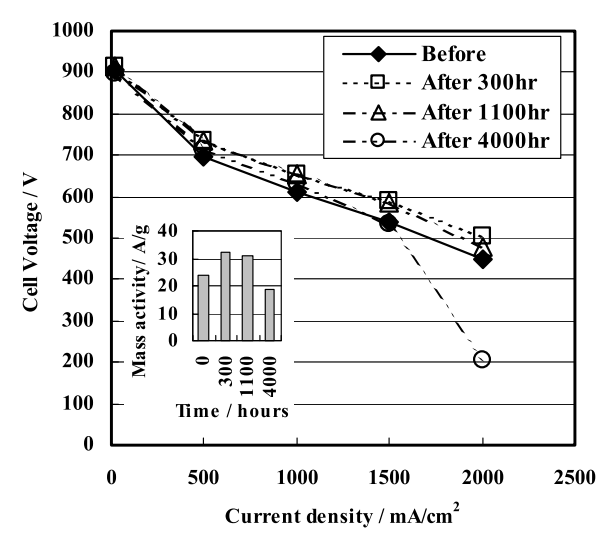

Fig 8 Polarization curve with $\mathrm{H}_{2} / \mathrm{O}_{2}$ at $80{ }^{\circ} \mathrm{C}$ before and after 300-, 1100-, 4000-hour life tests. (small graph) Mass activity at $0.9 \mathrm{~V}$ calculated from polarization curve as a function of lifetime. 
mance loss after life tests up to 1100 hours, while a large performance drop was observed in a current density region higher than $1500 \mathrm{~mA} / \mathrm{cm}^{2}$ after the life test for 4000 hours. There was no increase in internal resistance based on the current interruption method, therefore, this degradation in the higher current density region might be due to the loss of gas permeability of the cathode. Even if catalyst agglomeration was observed after the life test as reported previously, there was almost no sign of degradation of the catalytic activity as Fig. 8 shows. The same phenomena were reported by Wilson et al., ${ }^{3)}$ but many authors reported ${ }^{2,4,9,23)}$ that catalytic activity was decreased due to catalyst agglomeration after the life tests. It is still not clear, but there might be two explanations. One is that catalytic activity before the life test might be evaluated lower than its actual value because of insufficient pre-conditioning to evaluate the exact catalytic activity. The second is that this might be explained by the so-called "particle size effect" in which specific catalytic activity would become better with increasing particle size. ${ }^{24,25)}$

\section{2 Investigation of durability of CO-tolerance}

Figure 9 shows one of the results of life tests for 5000 hours using a supply of simulated fuel including CO without air-bleeding. A continuous performance drop was observed up to around 3000 hours, and the rate of degradation was calculated to be about $20 \mu \mathrm{V} / \mathrm{hr}$. After 3000 hours, because of several shutoffs caused by unexpected equipment error, the cell voltage started to oscillate, but the degradation rate appeared to remain the same. Another life test under the same conditions also showed almost the same trend. Figure 10 shows one of the results of life tests for 5000 hours using the simulated fuel including $\mathrm{CO}$ with $2 \%$ air-bleeding. A small performance drop was observed up to 4000 hours, and the degradation rate was calculated to be $7.5 \mu \mathrm{V} / \mathrm{hr}$. Around 4000 hours, because of a shutoff due to an unexpected error, there was a significant performance drop of about $40 \mathrm{mV}$. Almost the same trend was also observed in another life test under the same conditions. The reason was still not clear, and more experience will be neces-

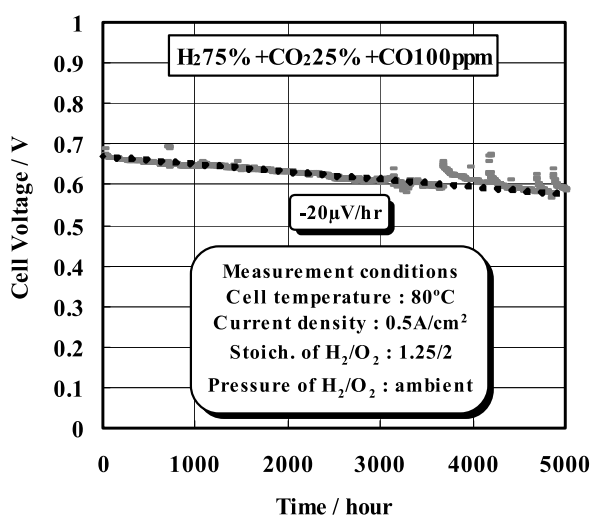

Fig 9 Cell voltage as a function of single cell runtime. Single cells were operated with $75 \% \mathrm{H}_{2}+25 \% \mathrm{CO}_{2}+$ $100 \mathrm{ppmCO} / \mathrm{O}_{2}$ (stoichiometry of $1.25 / 2$ ) at $0.5 \mathrm{~A} / \mathrm{cm}^{2}$ under $80{ }^{\circ} \mathrm{C}$. sary to understand this phenomenon.

Although cell performance degradation in the life tests under continuous operation might include cathode degradation and membrane degradation other than the degradation of CO-tolerance performance, it was clear that airbleeding could help to slow down the rate of cell performance degradation during the life tests with the simulated fuel including $\mathrm{CO}$. This should occur because degradation of the CO-tolerance performance of the platinumruthenium catalyst could be negligible during the life tests with air-bleeding, because CO-poisoning was very low under the condition with air-bleeding. In other words, the difference in the rate of cell performance degradation between the life tests with and without airbleeding could be considered to be the degradation of the CO-tolerance performance of the platinum-ruthenium catalyst. The degradation rate of the CO-tolerance performance of the platinum-ruthenium catalyst during the continuous life tests could be calculated to be 20 $7.5=12.5 \mu \mathrm{V} / \mathrm{hr}$. These results indicated that, from the standpoint of system operation, the air-bleeding technique might be an effective way to minimize cell degradation due to the loss of CO-tolerance performance of the platinum-ruthenium catalyst.

CO-tolerance performance without air-bleeding is greatly influenced by the surface conditions of the platinum-ruthenium catalyst. Therefore, evaluation of the CO-tolerance performance without air-bleeding before and after life tests might be a very effective way to analyze the change in the characterization of the platinumruthenium catalyst. Figures 11 and 12 show the CO-tolerance performance before and after the life tests with and without air-bleeding, respectively. In the case of the life test without air-bleeding, the voltage drop caused by $\mathrm{CO}$ was increased from $45 \mathrm{mV}$ to $49 \mathrm{mV}$ after 1000 hours, to $55 \mathrm{mV}$ after 2000 hours and to $118 \mathrm{mV}$ after 5000 hours. In the case of the life test with air-bleeding, the voltage drop caused by $\mathrm{CO}$ was increased from $45 \mathrm{mV}$ to $58 \mathrm{mV}$ after 1000 hours, to $66 \mathrm{mV}$ after 2000 hours, and to 124 $\mathrm{mV}$ after 5000 hours. That is, it was found that the COtolerance performance of the platinum-ruthenium cata-



Fig 10 Cell voltage as a function of single cell runtime. Single cells were operated with $73.5 \% \mathrm{H}_{2}+24.5 \% \mathrm{CO}_{2}+$ $100 \mathrm{ppmCO}+2 \%$ air $/ \mathrm{O}_{2}$ (stoichiometry of $1.25 / 2$ ) at $0.5 \mathrm{~A} / \mathrm{cm}^{2}$ under $80^{\circ} \mathrm{C}$. 


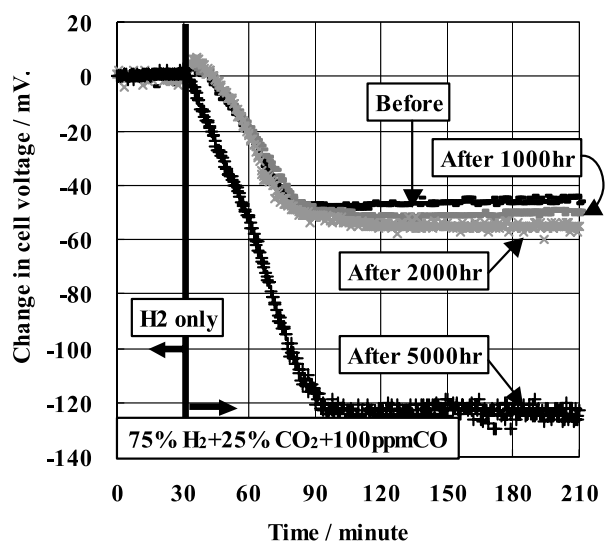

Fig 11 Change in cell voltage when fuel is changed from pure $\mathrm{H}_{2}$ to mixed fuel of $75 \% \mathrm{H}_{2}+25 \% \mathrm{CO}_{2}+100 \mathrm{ppmCO}$. Catalyst before and after 1000-, 2000-, 5000-hour life tests without air-bleeding was used for this measurement.

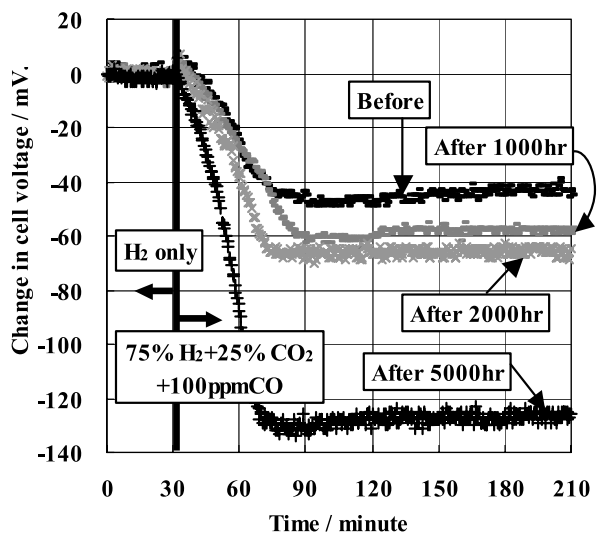

Fig 12 Change in cell voltage when fuel is changed from pure $\mathrm{H}_{2}$ to mixed fuel of $75 \% \mathrm{H}_{2}+25 \% \mathrm{CO}_{2}+100 \mathrm{ppmCO}$. Catalyst before and after 1000-, 2000-, 5000-hour life tests with air-bleeding was used for this measurement.

lyst was gradually damaged up to 2000 hours , and there was a significant loss in CO-tolerance performance after the 5000-hour life tests both with and without air-bleeding. These results could indicate that the characterization of the platinum-ruthenium catalyst was slightly changed after the life tests up to 2000 hours and that there should be a significant change in the characterization of the platinum-ruthenium catalyst after life tests for 5000 hours. This is not clear but because voltage oscillation was observed or a sudden performance drop after the life tests for more than 3000 hours maybe because of unexpected equipment error, there was a possibility that such unexpected events might accelerate the degradation of the CO-tolerance performance of the platinumruthenium catalyst. Therefore, more experimental life tests will be needed to evaluate the durability of the COtolerance performance of platinum-ruthenium catalysts after life tests for 5000 hours.

Figure 13 shows a comparison of TEM observations of a platinum-ruthenium catalyst before and after life tests for 5000 hours. Figure 14 shows the particle distribution obtained by TEM observation. There was almost no dif-



Fig 13 Transmission electron micrographs of platinumruthenium catalyst from (a) anode before life test (b) anode after 5000-hour life test without air-bleeding (c) anode after 5000-hour life test with air-bleeding.

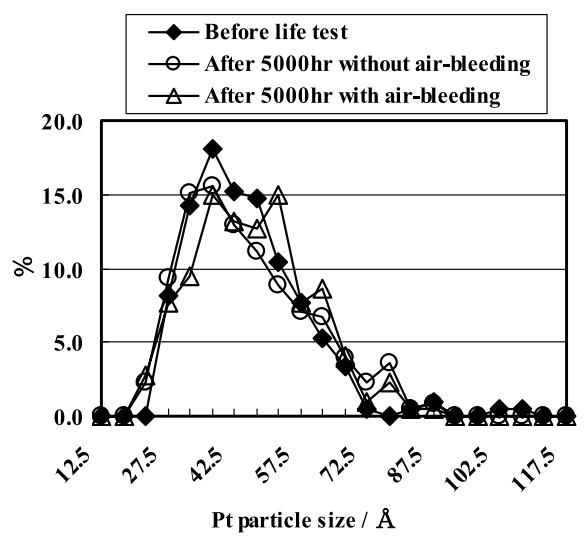

Fig 14 Catalyst particle size histograms measured from TEM micrographs in Fig. 13 (a), (b), and (c).

ference in particle size and particle distribution based on the TEM observation before and after the life tests. Table 1 shows a comparison of the peak angle and the full width of the half maximum (FWHM) of the PtRu(220) plane by XRD analysis. It was found that the FWHM was almost the same in each case, while the peak angle was slightly shifted to a smaller angle after the life tests. This could indicate that decomposition of the platinum-ruthenium alloy happened after the life tests, and this might lead to degradation of the CO-tolerance performance. However, the peak shift was very small and did not seem to be sufficient to explain the significant degradation of the CO-tolerance performance after the life tests. Especially in case of the life tests without air-bleeding, a change in the oxidized conditions of the platinum-ruthenium alloy surface and/or a change in the surface composition might also be considered the reason for degradation of the CO-tolerance performance after the life tests.

Figure 15 shows the increase in the voltage drop caused by $\mathrm{CO}$ from the initial value of voltage drop caused by $\mathrm{CO}$ as a function of lifetime based on all the 
Table. 1 Comparison of peak angle and FWHM of $\mathrm{PtRu}(220)$ plane by XRD.

\begin{tabular}{|l|c|c|}
\hline & Peak angle & FWHM \\
\hline Before life test & 69.08 & 2.305 \\
\hline $\begin{array}{l}\text { After 5000-hour life test } \\
\text { without air-bleeding }\end{array}$ & 68.94 & 2.127 \\
\hline $\begin{array}{l}\text { After 5000-hour life test } \\
\text { with air-bleeding }\end{array}$ & 68.52 & 2.248 \\
\hline
\end{tabular}

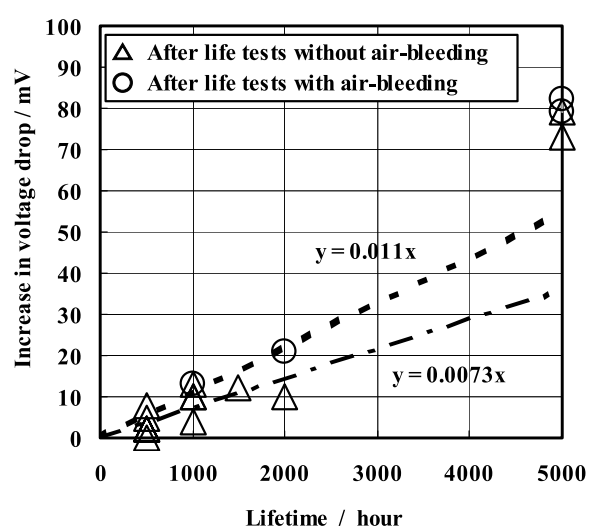

Fig 15 Increase in voltage drop caused by $\mathrm{CO}$ after life tests from the initial value of voltage drop caused by $\mathrm{CO}$ as a function of lifetime.

life tests carried out under the same conditions. It was found that the increase in voltage drop caused by $\mathrm{CO}$ was increased proportionally up to 2000 hours and seemed to be accelerated after 2000 hours in the life tests both with and without air-bleeding. However, because there was always some sign of performance degradation after the life test for 3000 hours or more due to unexpected equipment error as explained previously, the argument about degradation of the CO-tolerance performance after 2000 hours should be examined in the future. Up to 2000 hours, the voltage drop caused by CO increased with time proportionally, and the rate of increase in the voltage drop caused by $\mathrm{CO}$ was 7.3 $\mu \mathrm{V} / \mathrm{hr}$ and $11 \mu \mathrm{V} / \mathrm{hr}$ in the case of the life tests without and with air-bleeding, respectively. That is, air-bleeding could slightly accelerate the degradation of the CO-tolerance performance of the platinum-ruthenium catalyst. This indicated that the change in the characterization of the platinum-ruthenium catalyst might be slightly larger during the life tests with air-bleeding. This may be due to hydrogen combustion with air during air-bleeding on the catalyst surface.

Therefore, from the system point of view, air-bleeding should be an effective way to reduce the loss of cell performance due to the degradation of CO-tolerance performance of the platinum-ruthenium catalyst. However, from the material point of view, there is also a possibility that air-bleeding may slightly accelerate the catalyst material degradation.

\section{Conclusions}

Based on the investigation of the effect of operating conditions on catalyst agglomeration, catalyst agglomeration was found to be accelerated by higher temperature but not accelerated by higher current density $(\sim 1.5$ $\left.\mathrm{A} / \mathrm{cm}^{2}\right)$ nor by higher cell potential $(\sim 0.85 \mathrm{~V})$ when the operating temperature was $100{ }^{\circ} \mathrm{C}$. Also, catalyst agglomeration was found to continuously occur in the case of the cathode, while it happened only at the beginning in the case of the anode. The catalyst surface area of the cathode was reduced to almost half after 4000-hour single cell life test at $100{ }^{\circ} \mathrm{C}$ at a current density of 1.5 $\mathrm{A} / \mathrm{cm}^{2}$. This catalyst agglomeration might be caused by a crystallite migration mechanism and a coalescence growth mechanism because there was no sign of catalyst particles which were isolated from the electrochemical reaction and there was a peak tail in the direction of larger particles in the particle distribution after the life test.

Based on the investigation of degradation of the $\mathrm{CO}$ tolerance performance of the platinum-ruthenium catalyst, the CO-tolerance performance of the platinum-ruthenium catalyst was found to be gradually damaged during fuel cell operation. One reason for this degradation was considered to be decomposition of the platinum-ruthenium alloy. It was also found that loss of cell performance due to the degradation of the CO-tolerance performance may be negligible with air-bleeding, although catalyst material degradation might be slightly accelerated by the air-bleeding.

\section{Acknowledgement}

The authors would like to acknowledge Dr. Mitsushima of Yokohama National University for reviewing this manuscript and for providing substantial and helpful suggestions.

\section{References}

1) C. A. Raiser, L. Bregoli, T. W. Patterson, J. S. Yi, J. D. Yang, M. L. Perry, and T. D. Jarvi, Electrochem. SolidState Lett., 8, A273 (2005)

2) K. Mitsuda, H. Maeda, H. Fukumoto, H. Urushibata, M. Enami, and K. Takasu, Meeting Proceedings of 4th Fuel Cell Symposium, p103 (1997)

3) M. S. Wilson, F. H. Garzon, K. E. Sickafus, and S. Gottesfeld, J. Electrochem. Soc., 140, 2872 (1993)

4) P. J. Ferreira, G. J. la O', Y. Shao-Horn, D. Morgan, R. Makharia, S. Kocha, and H. A. Gasteiger, J. Electrochem. Soc., 152, A2256 (2005)

5) T. Tada, Handbook of Fuel Cells-Fundamentals, Technology and Applications, W. Vielstich(Ed.), H. Gasteiger(Ed.) and A. Lamm(Ed.), John Wiley \& Sons, Ltd, Vol.3, p.481 (2003)

6) K. Kinoshita, J. T. Lundquist, and P. Stonehart, J. Electroanal. Chem. Interfacial Electrochem. 48, 157 (1973)

7) T. Patterson, AIChE Spring National Meeting Proceedings, p.313 (2002)

8) R. M. Darling and J. P. Meyers, J. Electrochem. Soc., 150, A1523 (2003)

9) P. Yu, M. Pemberton, and P. Plasse, J. Power Sources, 144, 11 (2005) 
10) A. Taniguchi, T. Akita, K. Yasuda, and, Y. Miyazaki, J. Power Sources, 130, 42 (2004)

11) PCT WO 01/15247 (2001)

12) PCT WO 01/15254 (2001)

13) PCT WO 01/15255 (2001)

14) S. Ye, P. Beattie, and K. Bai, Meeting Abstract of 2005 Fuel Cell Seminar, CD-ROM (2005)

15) A. B. LaConti, M. Hamdan, and R. C. McDonald, Handbook of Fuel Cells-Fundamentals, Technology and Applications, W. Vielstich(Ed.),H. Gasteiger(Ed.) and A. Lamm(Ed.), John Wiley \& Sons, Ltd., Vol. 3, p.647 (2003)

16) D. E. Curtin, R. D. Lousenberg, T. J. Henry, P. C. Tangeman, and M. E. Tisack, J. Power Sources, 131, 41 (2004).

17) E. Endoh, S. Terazono, H. Widjaja, and Y Takimoto, Electrochem. Solid-State Lett., 7, A209 (2004)
18) A. Ohma, S. Suga, S. Yamamoto, and K. Shinohara, 73rd Annual Meeting of the Electrochemical Society of Japan, Abstr. p.412 (2006)

19) T. Tada, M. Inoue, and Y. Yamamoto, Meeting Abstract of 2000 Fuel Cell Seminar, p.59 (2000).

20) T. Tada, M. Inoue, and Y. Yamamoto, 3rd International Fuel Cell Conference Proceedings, p.107 (1999)

21) S. Gottesfeld and J. Pafford, J. Electrochem. Soc., 135, 2651 (1988).

22) C. G. Granqvist and R. A. Buhrman, J. Catal., 42, 477 (1976)

23) S. G. Yan, H. A. Gasteigher, J. Doyle, and T. Faben, 15th World Hydrogen Energy Conference Abstracts, p.255 (2004).

24) K. Kinoshita, J. Electrochem. Soc., 137, 845 (1990)

25) Y. Takasu, T. Kawaguchi, W. Sugimoto, and Y. Murakami, Electrochem. Acta, 48, 3861 (2003) 